Check for updates

London, UK

Cite this as: BMJ 2021;375:n2811 http://dx.doi.org/10.1136/bmi.n2811 Published: 23 November 2021

\section{Cradle to grave general practice: the family doctor}

\section{The GP partner and trainer talks to Francesca Robinson about his commitment to his patients and training the next generation}

\section{Francesca Robinson}

At the age of nearly 70 Joe Cohen still works a four day week in his general practice in east London and struggles with the thought of retirement. He cares deeply for his patients, many of whom he has known for almost 25 years. He would also miss seeing his registrars develop into fully fledged GPs.

Cohen chose a career in general practice in 1979. As a senior registrar in general medicine, a local GP asked him to cover his practice for a week. "I knew nothing about general practice, but that locum changed my life forever. I became addicted to family medicine, sharing patients' concerns, and offering continuity of care. I never looked back.”

He has been qualified now for 46 years and has loved every minute. "I am at my desk by 730 am and rarely leave before $730 \mathrm{pm}$. I never consider what I do as work," he says.

Cohen likes to be seen as part of his patients' lives. For him empathy with his patients' concerns is fundamental. "I never get cross seeing patients with minor ailments; there is often an over-riding reason why they attend," he says. "I always ask them, 'Why now? What made you come today and not tomorrow?"”

He emphasises to his registrars the importance of apologising to patients when things go wrong even though this can be painful. He also believes in the importance of valuing practice staff-remunerating them well, listening to their concerns, and acknowledging their worth-because the practice works as a team.

Cohen invariably writes to bereaved families, offering condolences and support. Before general practice became so busy he used to visit his patients in hospital-to the astonishment of ward staff.

Education is Cohen's other passion. Over the years, he has trained nearly 30 registrars. "I love teaching, and seeing registrars develop," he says. "We have a duty to pass on our skills and knowledge. Teaching should be fun, entertaining, and humorous. If you laugh at something, or cry, you are more likely to remember it. I never demean or humiliate learners.”

During the 1980 s Cohen left general practice for a decade and single handedly conducted his own course for thousands of junior hospital doctors taking their Membership of the Royal Colleges of Physicians exam. He now runs the Cohen clinical skills assessment and recorded consultation assessment course with his GP son, Nathan, for specialty trainee year 3 (ST3) GP registrars.
Since 2013 Cohen has chaired the Redbridge Clinical Commissioning Group's protected learning event (PLE), which provides monthly learning for GPs.

He will retire reluctantly. "I can't say the word 'retirement.' I don't want to let go, but I will next August when my current ST3 qualifies," Cohen says. "Two friends, younger than me, died recently. I don't want to retire only to find I've only got a few years to live."

In retirement, Joe plans to continue teaching through the PLE, vocational training schemes, medical students, and his Membership of the Royal College of General Practitioners course. "My registrars have kept me going more than anything else. Helping doctors pass their exams has been inspirational. After 46 years it is still an absolute joy," he says.

On reflection, Cohen says the most fulfilling aspect of his career has been medical education and patient care. "As GPs and trainers, we are in a privileged position. It is an absolute duty for us to pass our experience to future generations.”

\section{Nominated by Ross Cunningham}

"Dr Joseph Cohen has an astonishing commitment to training. He is almost 70 and he shows little sign of slowing down. His knowledge of his patients and his care for them is inspiring, and he continues to be fascinated by the art of general practice and the diagnostic conundrums GPs face. It doesn't matter how early I arrive or how late I leave-he will be at his desk. His door is always open, and his stock of anecdotes is profound. GP training in our area will be immeasurably poorer when, or if, he ever does get round to retiring."

Ross Cunningham is a GP trainee at the Glebelands Practice, London

To nominate someone who has been a role model during your medical career, send their name, job title, and the reason for your nomination to tmoberly@bmj.com. 